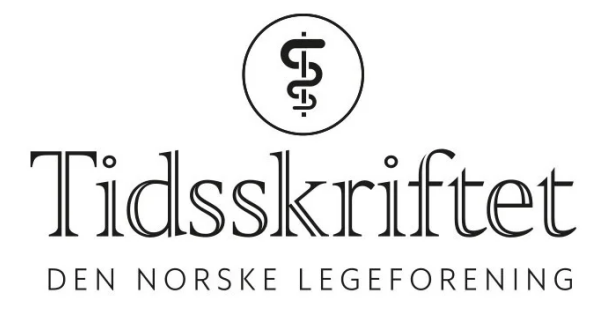

\title{
Sinn, kropp og sykdom
}

INTERVJU

\section{MARIT TVEITO}

Email: marit.tveito@me.com

Vinderen DPS

Øivind Ekeberg har en uvanlig posisjon som psykiater ved en akuttmedisinsk avdeling. Han har i over 30 år stått støtt i traumer, kriser og hverdagskatastrofer. Men hva gjør egentlig en psykoanalytiker på intensiven? Og hvorfor kan han så mye om flyskrekk?

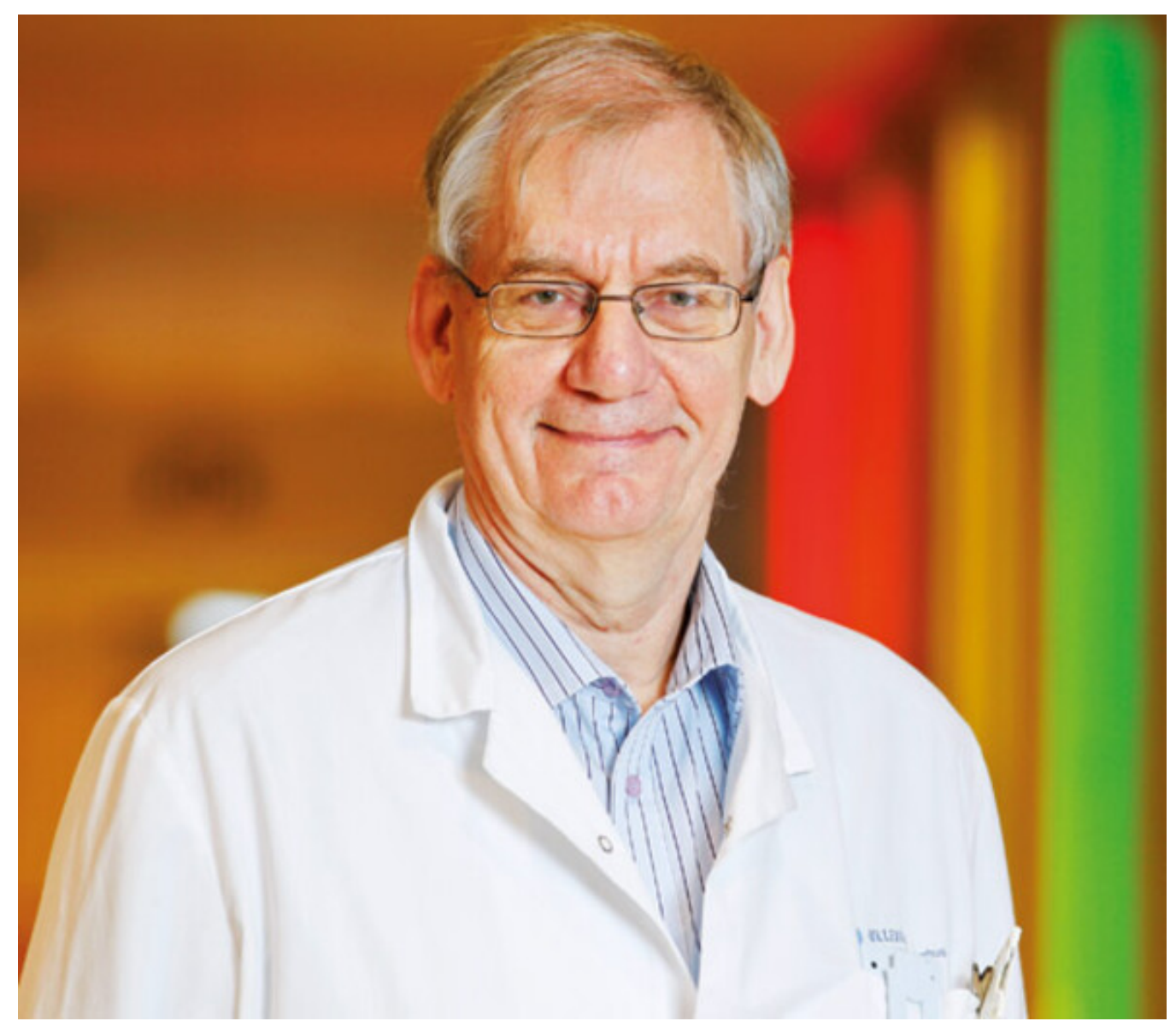


Foto Mosvold/SCANPIX

Ekeberg er fra Kolsås, der han bor i «maleriske» omgivelser. Knut Kvernebo, god venn og kollega, ble overrasket da han spaserte blant impresjonistene på Musée d'Orsay i Paris. Er det ikke gården til Øivind? tenkte han da han tok et bilde av Monet i nærmere øyesyn. Og det var det. Monet befant seg vinteren 1895 i Norge. Han ville male det «fryktinngytende nord» og satte seg ned med utsikt fra Kolsåstoppen.

- Gårdsdriften er det slutt på?

- Det var aldri snakk om å drive gården, sier Ekeberg. - Jorden var forpaktet bort allerede da jeg var ung. Jeg valgte Handelsgym, tenkte det ville gi meg mange muligheter. Etter artium begynte jeg på sosialøkonomi, men ble raskt klar over at det var et blindspor og bestemte meg for å satse på medisinen.

Mange er glad for det valget. Kolleger beskriver Ekeberg som dyktig og allsidig. Han har hele karrieren vært akademisk aktiv og er en ettertraktet veileder for stipendiater. Han omtales som «storprodusent» av doktorgrader og studentoppgaver. Det dreier seg om alt fra forgiftninger og hypertensjon til flyskrekk og kommunikasjon i intensivavdelinger. En kollega fra medisinsk avdeling omtaler Ekeberg spøkefullt som den mest normale psykiateren han vet om. Han er dessuten kjent for å ha omsorg og omtanke for kolleger, særlig for dem som har vært ute i hardt vær.

\section{Psyke og soma}

- Du er nesten «fullgod» indremedisiner i tillegg til psykiater. Hva fikk du interesse for først?

- Etter turnus begynte jeg ved psykiatrisk avdeling, Ullevål. Så fikk jeg ett års sideutdanning ved medisinsk avdeling 7 . Det ble avgjørende i min karriere og ga meg muligheten til å kombinere interessen for soma og psyke. Jeg fikk god kontakt med Erik Enger, sjefen ved medisinsk avdeling, som ønsket å opprette en stilling for meg. Han hadde på denne tiden sentralisert forgiftningsbehandlingen og så behovet for et videre perspektiv på pasientene.

- Hva besto dine oppgaver i?

- Jeg har alltid hatt en klinisk stilling, men Enger lot meg bruke tid også på forskning. Han ga meg frie rammer, støttet og veiledet. Jeg bygde opp professorkompetansen i denne jobben og har aldri hatt forskningsstipend. Jeg synes jeg har vært heldig, jeg kjenner ikke til andre psykiatere som er ansatt ved en akuttmedisinsk avdeling. Det er utradisjonelt, på samme måte som doktorgradsarbeidet mitt.

\section{Flyskrekk}

Doktorgraden omhandlet flyskrekk, visstnok den første undersøkelse av sitt slag i verden.

- Hvorfor flyskrekk?

- Jeg skulle egentlig skrive om forgiftninger, men begynte nokså tilfeldig å holde flykurs hos Braathens i 1983. Kurset var kognitivt vinklet, med vekt på læring, og ble avsluttet med en flytur. Deltakerne fylte ut skjemaer ved starten, etter kurset, så etter et halvt år og igjen etter to år. Intervensjonen hadde uttalt klinisk effekt. Vi viste at kurset reduserte redselen for å fly. Deltakerne brukte mindre beroligende medikamenter og fløy mer, og effekten holdt seg etter to år. Jeg ble nysgjerrig på fenomenet og gjorde en befolkningsunders $ø$ kelse via Statistisk sentralbyrå. Forskningen ble stadig utvidet. Vi tok blodprøver, puls og blodtrykk på kursdeltakere og tilfeldige passasjerer under flyturer. En gang chartret vi et helt fly for å undersøke effekten av selektiv betablokade hos dem som sto på venteliste til kurs.

- Dere fløy, skrev og publiserte? 
- Vi skrev artikler om resultater og funn. Uten å ha planlagt det hadde jeg plutselig nok til en doktorgrad. Enger lot meg skifte tema. Jeg fikk overlegepermisjon for å skrive et sammendrag, det er det jeg har hatt av heltids forskningstid.

- Hvorfor ble du værende i skjæringspunktet mellom psykiatri og somatikk?

- Jeg hadde veldig sans for den somatiske medisinen, og føler meg heldig som har fått jobbe i et grenseområde. Jeg har én definert universitetsdag. Klinikken består ellers mye i å gjøre akutte vurderinger av pasienter i alvorlige kriser og sørge for adekvat oppfølging. Jeg tar også imot noen pasienter selv, i 20 \% privatpraksis med hjemmekontor.

Han trives med å jobbe hjemme. - Da virker det mer naturlig at man går med tøfler, sier han og smiler. - Dessuten er det «diskré» å komme hjem til meg, og for noen er det viktig. Jeg har hatt muligheten til å følge opp enkelte jeg har vært spesielt bekymret for. Det er mye som skjer på sykehusene, og kolleger kan også trenge støtte. Jeg har nok relativt sett mer helsepersonell på listen enn det er vanlig å ha. Jeg er utdannet psykoanalytiker og synes mulighet for behandling over tid er viktig, selv om jeg ikke driver med regulær analyse. Man kommer ikke alltid til målet med korte, kognitive intervensjoner når problemene er sammensatte.

\section{Studentene}

Ekeberg underviser medisinstudenter i atferdsfag og veileder både studenter og stipendiater.

- Det er en stor glede og utfordring å arbeide med studentene. Undervisningen i klinisk kommunikasjon gir dem anledning til å få innsikt i samspillet mellom pasientenes somatiske, psykiske, sosiale og eksistensielle helseproblemer. Ved bruk av egnede pasienter får de muligheten til å tilegne seg kunnskaper og ferdigheter som de aldri kan få fra en lærebok. De lærer både å ta imot og gi konkret og konstruktiv feedback. Ikke minst er det inspirerende å se hvordan de utvikler seg fra midt i studiet å kunne kartlegge helseproblemer til å kunne gi informasjon om alvorlig sykdom rett før de skal ut i turnustjeneste.

\section{Når det stormer i mediene}

- Det er kjent fra mediene at du har vært en viktig støtte for ambulansesjåføren Schjenken.

- Det er ikke noen hemmelighet at jeg har jobbet med flere ansatte ved sykehuset som har vært medieeksponert. Det har innimellom vært en ugrei håndtering av egne ansatte fra sykehusets side. Flere har fått svakt begrunnede advarsler, som er blitt trukket tilbake i etterkant. Jeg har prøvd å gi tilbakemelding på at man må være bevisst skadepotensialet når det gjelder denne type eksponering.

- Hva skjer med dem som havner i en slik situasjon?

- Den personlige integriteten blir truet. Vi snakker om et nytt syndrom, medieoffersyndromet. Det er en form for posttraumatisk stressyndrom, med typisk intrusjon, unnvikelse og autonom aktivering. Vi har dessverre også sett noen selvmord som følge av slik eksponering. Det som er spesielt ved overeksponering i mediene, er den psykiske trusselen. Det stilles også spørsmål ved ens faglighet, ofte i fordreid og repeterende form. De dette gjelder, har ikke ønsket medieeksponering, og plutselig befinner de seg i riksdekkende medier. Hvis arbeidsgiver ikke forsvarer dem, kan situasjonen bli ekstra traumatisk. Man må skille mellom å forsvare personen og forsvare handlingen. Når en ansatt ikke blir forsvart som person, men tvert imot skviset ut, viser det behovet for en gjennomgang av reaksjonsmåter og holdninger.

- Er helsepersonell mer utsatt enn andre for stress i slike situasjoner? 
- Helsepersonell har vanligvis ikke trening i forhold til mediene. Dessuten er pasienthistoriene ofte emosjonelt ladet. Det kan fort bli et misforhold mellom feil som gjøres og personeksponeringen.

- Hva gjør slike hendelser med andre ansatte i helsevesenet?

- Det skapes usikkerhet. Å sette søkelys på feil er viktig og nødvendig, men vi er kommet til et punkt hvor vi er så opptatt av å gardere oss at vi kan gjøre mye unødvendig. Vi kan neppe stoppe medieutviklingen, men man må være oppmerksom på hvordan dette fungerer og tenke kollegialt. I tillegg er det viktig å legge vekt på lederansvaret. Man må ta vare på medarbeidere som har gjort feilvurderinger.

\section{Omskiftelige tider}

- Mer generelt: Hvem skal lede og ta seg av de ansatte ved sykehusene?

- Jeg har valgt ikke å bli leder selv. Jeg har foretrukket å jobbe med faget, pasientene, stipendiatene og kollegene og er vel derfor ikke så meningsberettiget når det gjelder temaet lederskap. Men jeg tror det finnes myter om hvem som bør være i lederposisjoner. Det er for liten bevissthet om forskjellen på administrasjon og ledelse. De som sitter som ledere, er ofte for involvert i den daglige driften, men mangler kanskje friheten til å løfte blikket og se fremover.

- Man kan få inntrykk av at ansatte ved Oslo universitetssykehus føler at det er vanskelig å tenke fremover når tidene er så omskiftelige. Hva gjør de stadige omstillingene med folk?

- Gaius Petronius (død 66 e.Kr.) sa noe om hvor sliten og desillusjonert man blir av gjentatte omorganiseringer. Det er mer sant nå enn noen gang. Det virker som det er få som først spør: Har vi et problem? Hva består det i? Hvordan skal vi løse det? I stedet har endringsprosesser startet fra toppen med en rekke honnørord. Det pekes i ulne ordelag på at vi må effektivisere. Nå skal vi lage Europas største sykehus basert på en innstilling som er en 20 siders oppramsing av vakre vendinger, men helt fri for analyser. Noen mener at en professor ikke både kan lede en avdeling og drive med klinisk arbeid og forskning. Det er et paradoks at en middelmådig skuespiller kan lede USA, mens en professor ikke kan lede en avdeling med 30 senger. Det er ingen automatikk i at man egner seg som leder ved å være professor, men det bør absolutt ikke være diskvalifiserende.

\section{Om selvmord}

- Noen har foreslått en nullvisjon for selvmord. Hva tenker du om det?

- Man kan gjerne ha en visjon om null selvmord, null branner, null trafikkulykker og null fødselskomplikasjoner, men man skal passe seg litt for å ha for mange urealistiske vyer.

- Hvor går veien videre for å forebygge selvmord?

- Det er vanskelig å svare på det. Problematikken er kompleks. Fenomenet har affinitet til tidsånd, samfunnsproblemer, meninger og verdiinnhold i livet. Dette handler om noe mer enn det helsevesenet isolert sett kan gjøre noe med. Vi kan si noe om risikofaktorer og gi anbefalinger om hva man skal gjøre. En nullvisjon for dødsfall i trafikken er nokså enkelt å oppfylle, det er bare å senke fartsgrensen til $15 \mathrm{~km} / \mathrm{t}$. Da vil ingen dø, men det er ikke gjennomførbart. En så enkel modell kan vi ikke lage for selvmordsforebygging. Det eksisterer imidlertid åpenbare svakheter i oppfølgingen etter selvmordsfors $ø$ k. Vi vet at risikoen for død er minst like høy som etter førstegangs hjerteinfarkt, men oppfølgingen er mer strukturert etter infarktet.

-Er ikke dette tankevekkende?

- Det burde vel ikke være slik. Det er viktig å øke fagligheten innen selvmordsoppfølging. 
- Er det helsevesenet som svikter når et menneske tar sitt eget liv?

- Noen suicidaltilstander er dødelige nesten uansett hva man gjør. Vi må kunne skille mellom forsømmelser og medisinske feil og det som er upåregnelig. I ettertid er det alltid mulig å tenke seg at man kunne gjort noe annerledes. Det innebærer for helsepersonell at det er kort vei til urimelig kritikk. Da er det viktig med god, saklig kollegial tilbakemelding og støtte. Det er uansett tøft for den som mister pasienter i suicid. Det kan skje, slik man også mister pasienter i forbindelse med behandling av kreft eller hjertesykdom. Veien til selvbebreidelse og kritikk fra andre er likevel mye kortere.

- Du har forsket på mye og veileder bredt. Er det nye temaer du har lyst til å ta fatt på?

- Prognosen er alvorlig for dem som har forsøkt å begå suicid. Vi har svært få studier på effekten av intervensjon, nasjonalt og internasjonalt. Vi vet at mye av det som utløser suicidal atferd taler for lengre tids behandling. På dette området har vi en forskningsutfordring. Vi holder nå også på med en studie for å se på dem som er innlagt etter suicidfors $ø \mathrm{k}$ med voldsomme metoder. Vi tror at det hos denne pasientgruppen er en mer alvorlig psykopatologi enn hos andre. Et annet område det bør satses mer på er psykotraumatologi.

\section{Traumer}

- Du har jobbet mye med mennesker som har vært utsatt for traumer?

- Jeg har ledet det psykososiale kriseteamet ved Oslo universitetssykehus, Ullevål, i noen år. Vi var i aktivitet i sammenheng med tsunamien i 2001 og nå i forbindelse med 22. juli. Sykehuset håndterte utfordringene med disse katastrofene på en god måte. Vi gikk tungt inn overfor både pasienter og pårørende. Pårørende har mye symptomer, det har vi konkret kunnskap om etter tsunamien. Mange hadde faktisk like sterke symptomer som de som fysisk hadde vært rammet av bølgen.

- Hva mangler i traumebehandlingen?

- Noe av det som bekymrer, er konsekvensene av hverdagstragediene. Mange liv snus på hodet hver eneste dag. De pårørende kan sitte på sykehuset i dagevis og ukevis mens deres kjære svever mellom liv og død. Her kan vi kanskje kartlegge bedre hvem som trenger støtte. En ønskedrøm hadde vært en egen poliklinikk til å følge opp pasienter og pårørende som har behov for hjelp i etterkant.

Tiden løper fra oss - Ekeberg er allerede for sent ute til neste møte. Vi har ikke rukket å snakke om hobbyer som sjakkspill, tennis og skiturer. Heller ikke om hans fortid som politiker med erfaring fra kommunestyre og fylkesting. Hullene i et intervju kan bli store når interessene er mange og engasjementet stort.

Litt senere på kvelden kommer det en e-post tikkende inn, med følgende sluttkommentar: «Som du skjønner jobber jeg med mye og har lange dager. Men basen er i hjemmet, og det er det viktigste av alt. I avhandlingen skrev jeg følgende dedikasjon: To Karin, for fidelity, care and support. To Aleksander and Carl Fredrik, for all your smiles, spirit and confidence. Det var jeg ganske fornøyd med, og enda mer fornøyd med at det gjelder like mye i dag.»

\section{Tabell}


Øivind Ekeberg

Født 20. januar 1945

- Cand.med. 1973 fra Københavns Universitet

- Spesialist i psykiatri 1980

- Dr.med. Universitetet i Oslo 1991

- Overlege i psykiatri ved Akuttmedisinsk avdeling, Oslo universitetssykehus, Ullevål

- Professor II ved Avdeling for atferdsfag, Institutt for medisinske basalfag,

Universitetet i Oslo

Publisert: 24. januar 2012. Tidsskr Nor Legeforen. DOI: 10.4045/tidsskr.11.1484

(C) Tidsskrift for Den norske legeforening 2023. Lastet ned fra tidsskriftet.no 26. april 2023. 